\title{
HOXB Gene Family
}

National Cancer Institute

\section{Source}

National Cancer Institute. HOXB Gene Family. NCI Thesaurus. Code C105822.

A family of genes found in a cluster on the $q$ arm of chromosome 17. These genes

encode transcription factors that play a role in gene expression, cell proliferation and cell differentiation. 